\title{
THE SELECTION OF KRAMA LEXICON IN POLITE SPEECH OF SEMARANG COASTAL COMMUNITY
}

\author{
Fitri Windaryanti, M. Suryadi \\ Magister Ilmu Linguistik, Universitas Diponegoro, Indonesia \\ Jalan Prof. Soedarto 13, Tembalang, Jawa Tengah, Indonesia \\ Corresponding Author: fitriwindaryanti@students.undip.ac.id
}

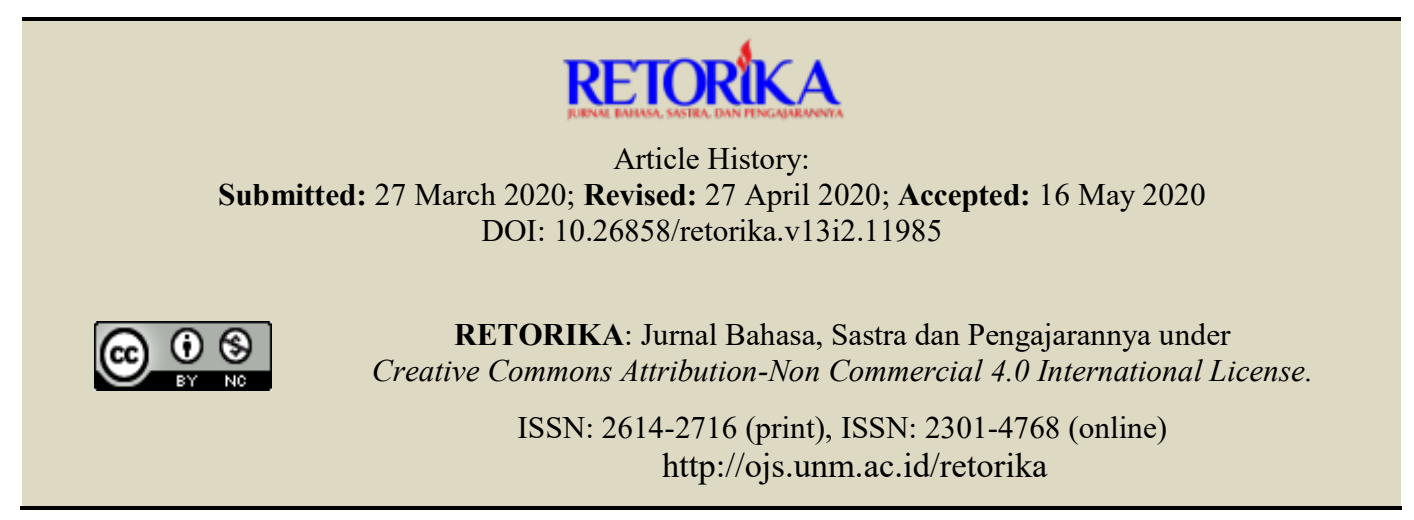

\begin{abstract}
This research aimed to describe the proficiency, selection and placement of krama lexicon. A sociolinguistics approach with the utilization of a descriptive qualitative collaborative method was used in the data analysis. The qualitative analysis employed bagi unsur langsung (BUL), permutation, and substitution methods. The results showed that: (1) the lexical proficiency of krama from Semarang coastal community reached 38.1\%, (2) Javanese language contained overlapped speech, (3) there was self-kramanisasi in Javanese language, and (4) there was Indonesian language interference on Javanese. The deviations were caused by an error in language inheritance, low proficiency in krama lexicon, and the lack of comprehension of the Javanese speech levels usage.
\end{abstract}

Keywords: Javanese coastal language, lexicon, krama, polite speech

Javanese is a rich language that has high politeness value. The Javanese language is used to express everything that becomes the wealth of the speaker so that the Javanese language becomes the identity for speakers of the Javanese language itself (Sudaryanto, 1991). The main functions of Javanese language are: (1) as a binding of kinship and offspring emotion (in terms of the family); and (2) as the identity as well as a tool of communication in a community. However, it cannot be denied that in its development, the Javanese language has changed its function which is influenced by the geographical location (for example: coastal areas), Javanese speakers' traditions, and economic competition (Suryadi, 2014). Javanese language has a fairly large number of speakers and is spread almost all over Indonesia. As a language with a large number of speakers, Javanese language has experienced a lot of depreciation, both in quantity and quality. Quantity depreciation is characterized by a reduction in the number of speakers, the average number of Javanese speakers in urban areas is less than $40 \%$ (Santoso, 2006); even in the city of Semarang, there are only $26.16 \%$ (Handono, 2004). 
According to (Pujiastuti, S., Surono, \& Mayzah, 2009), Javanese speakers in Semarang who master Krama are only $12.5 \%$. Depreciation in quality is characterized by the fragility of mastery of Javanese language and the reluctance to speak Javanese in daily activities by Javanese speakers in coastal areas. As a result, the role and function of the Javanese language in the coastal area experienced a significant change, namely a change in the form of politeness in speech to become more egalitarian and egocentric. Furthermore, Javanese language is increasingly abandoned by its speakers (Laksono, 2006).

The north coast area is analogous to an area where the Javanese language is becoming increasingly scarce considering that besides being an area far from the palace as the center of Javanese culture, this area is also a border between two regions, namely land and sea. The coastal area chosen as the research area is Semarang City because the people of Semarang City can be categorized as diverse communities; both in terms of economic, social, and language. This diversity seems to be related to increasingly high population mobility and complex social networks, so it is very influential on lexical mastery and lexical selection in its use in everyday speech. This research was focused on the selection of Krama lexicon as well as the deviation of lexical selection in polite speech sentences which are influenced by the level of Krama lexical mastery in the coastal area of Semarang City.

The measurement of the Krama lexical mastery level is very important because, through Krama lexical mastery, we can measure the ability of speakers to choose and place the krama lexicon in sentence speech. The selection of krama lexicon influences the sentence form used in the speech of coastal community in Semarang City. The selection and placement of the lexicon that is not following the rules raise some interesting deviations to be explored. Therefore, to be able to find a model of polite speech of the Coastal Javanese community, the above language phenomenon was raised in the research of "Krama lexical selection in Polite Speech of Semarang Coastal Community". This research utilizes the results of previous research as a material for consideration and reference, namely research-oriented purely on the Javanese language as a lingual system (langue), researchoriented to the coastal area, and research-oriented to the speech component.
One of the studies of the Javanese language of the coastal community was written by (Azizah, 2008). She examined the form of speech or language selection (between $\mathrm{BI}$ and $\mathrm{BJ}$ ) in a household and the factors underlying the frequency of use of the language. The results showed that Javanese still plays an important role as a means of communication, expression, and interprettation in social life in two research areas. Differences in age, level of education, and social status of a speaker affect the selection of language used by the respondent. Based on the underlying factors, it can be said that the selection of Javanese speech forms by respondents in the household domain is fixed / stable, even though they are in different portions. The reason of the research (Azizah, 2008) becomes a reference source is because the object of research and theory used almost the same in this research.

In different research by (Suryadi, 2014), he aims to find out the role of family and community in the use of Javanese language in Semarang and Pekalongan City. The results of the research include: (1) There is a weak role of family and community in inheriting standard Javanese languages, namely standard Javanese language or SoloJogja Javanese language which have a set of standardized and maintained rules (Sudaryanto, 1991); (2) The lexical mastery of the young generation is in poor qualification, namely $41.1 \%$ (Semarang City) and 46.1\% (Pekalongan City); (3) A portrait of the use of Javanese language in the cities of Semarang and Pekalongan; (4) features of Semarangan language and Pekalongan language can be taken as a portrait of some Javanese languages used in the North Coast region of Central Java; and (5) significant differences between Javanese speakers in the cities of Semarang and Pekalongan.

Furthermore, the research (Suryadi, 2015) describes the uniqueness of Semarang polite speech, the uniqueness side that was investigated was the behavior of Semarang Javanese speakers in placing krama ingil lexicon on polite speech as a sign of politeness. The results of the research found out that the uniqueness of Semarangan language's polite speech is contradicting the rules that apply to the standard Javanese language. There are two uniqueness found, namely: (1) the krama inggil lexicon aside from addressing the interlocutor can also be addressed to the speaker, 
and (2) although the lexicon of krama inggil is attached to the speaker, it is still used to respect the interlocutor.

Similar research was studied by (Wibawa, 2015). The research topic is the inaccuracy in the use of Javanese language in ngoko, madya, and krama politeness speech levels of Javanese language education program students. The results showed the inaccuracy in the use of krama alus, krama lugu, madya, ngoko alus, and ngoko lugu. The inaccuracy in the use of Javanese language is most prominent in the use of krama alus speech level, $76.13 \%$ of the number of cases researched. The inaccuracy is due to the inaccurate use of vocabulary in each speech levels.

Another research (Sundoro et al., 2018) with research data in the form of speech sentences that indicate the mixing of the Banyumas Javanese language code with the Indonesian language between the teacher and students during the Indonesian language lesson. The results showed a mixed code in the form of (1) insertion of words, (2) insertion of phrases, (3) insertion of clauses, (4) insertion of repetition of words and (5) insertion of expressions. The mixing of the code was due to: the situation changes, the speaker wants to explain something, and to establish the intimacy between the teacher and students. This research is used as one of the references because it is related to the code-mixing and interference phenomenon that exists in the Javanese language in the coastal area of Semarang City.

Based on the results of research that has been done before, this research will examine the selection of the krama lexicon in the polite speech of the Semarang coastal community which has never been examined in previous studies. Through this research, the researcher can also explain the factors that cause the selection of the krama lexicon in a polite speech that is used daily by the community in the research areas.

\section{METHOD}

The research was conducted in the city of Semarang. The selected research areas were urban and settlement areas with five observation points, namely North Semarang District, West Semarang District, Central Semarang District, Genuk District, and Tembalang District.

The respondents and informants were Javanese speakers, from Javanese families (Javanese husband and wife), and permanent residence (at least five years) in the research area. Respondents with a total of 38 people representing each research area. The respondents chosen were Javanese families in Semarang City, between the ages of 25-60 years with emotional and economic stability consideration. Another reason that underlies the selection of respondents and informants in this research is that the coastal com-munity of Semarang represent the use of language and communication etiquette of lower-class people who are far from the influence of the traditional noble lifestyle or the palace environment in daily interactions (Purwoko, 2008).

The data in this research included primary data and secondary data. Secondary data were obtained by referring to the advanced technique: note-taking technique (Sudaryanto, 2015). Primary data collection was done by methods of: observation, structured interviews, and in-depth interviews. The observation method was used to get a general description of the location and object of research.

Structured interviews were used to obtain information about the settings of coastal Javanese speakers. Structured interviews were conducted by asking several questions to the respondent based on the questionnaire. A list of questions was structured and made based on the findings made at the observation stage. The questionnaire contained the informant's personal data and research core questions. Personal data included: name, address, gender, age, education, occupation, religion, and social status. Technically, personal data was obtained at the end of data tapping. This was done to maintain data purity. The questionnaire attempted to elicit: (1) mastery of the Javanese lexicon with a question table containing 100 basic lexical mastery in the variety of ngoko and krama (krama lugu and krama inggil); (2) linguistic settings that contained questions on the use of language in daily life; and (3) the selection of the lexicon in the speech sentence by transliterating 100 simple speech sentences from Indonesian language to Javanese. This aimed to obtain the condition of language related to the selection of the krama lexicon to speak politely.

In-depth interviews were conducted by asking questions verbally to obtain language aspects of the Semarang coastal community. The aspects obtained by in-depth interviews were (1) 
the mastery of the lexicon of krama in the speech of Javanese coastal community in the city of Semarang and the factors underlying the level of mastery of the krama lexicon, (2) the form of selection and placement of the krama lexicon in Javanese speech of Semarang coastal community and factors determining whether or not the sentence is correct if it is measured by prescriptive normative of Javanese language.

The validity of the data does not only depend on the accuracy of choosing the data collection techniques, but also requires the development of the validity of the data as well. The validity of the data can be used as a guarantee of the conclusion validity of the research results. The data validity development technique used is the triangulation of data sources. The triangulation of data sources is to explore the truth of certain information through various methods and sources of data acquisition (Bachri, 2010). Different respondents certainly have different experiences and perceptions of the data, through various data collection techniques applied, the results could be close to the truth. Data triangulation in this research was conducted by comparing three sources of data acquisition, namely the acquisition of data from observations, structured interviews (with research instruments), and indepth interviews.

The data were analyzed using a sociolinguistic approach with quantitative and qualitative collaborative methods (descriptive qualitative collaborative). Quantitative analysis is used to measure the level of krama lexical mastery in Semarang coastal community and to strengthen the results of qualitative research. Whereas qualitative analysis is used to find out the factors underlying the selection and placement of the lexicon in the speech of Semarang coastal community. The qualitative analysis utilizes the metode agih (distributional method) with basic techniques: bagi unsur langsung (BUL), and advanced techniques: mutation and substitution techniques. The results of data analysis are presented descriptively.

\section{Testing Technique of Krama Lexical Mastery of Semarang Coastal Community}

The krama lexical mastery test was conducted quantitatively to Javanese speakers of Semarang coastal community to measure their krama lexical mastery on various basic krama lexicon types: krama lugu and krama inggil. The testing technique of krama lexical mastery in Javanese speakers of Semarang coastal community was done by giving them a vocabulary test, where they have to translate the Indonesian lexicon into the Javanese lexicon, specifically into ngoko and krama (krama lugu and krama inggil). There are 100 (one hundred) basic lexicon that often appears in everyday speech sentences.

The assessment technique was done by giving a score on each answer from the informant. Each correct transliteration result from Indonesian language to Javanese language krama ( $k r a-$ ma lugu and krama inggil) gets a score of 1 (one) and gets a score of 0 (zero) if the translation is incorrect. Thus, the numbers listed in the valuation are 0 (zero), 1 (one), and 2 (two). 0 score means all the translation wrong; 1 score means there is 1 mistranslation; and a score of 2 means all translation is correct. The informant will get a score of 200 (two hundred) if all the translation is correct. The score was calculated using the formula from (Suryadi, 2014) in table 1 below.

Table 1. Percentage Formula of Krama Lexical Mastery

$$
\begin{aligned}
& \frac{\text { number of correct answer }}{200} \times 100 \%=\text { Percentage of } \\
& \text { krama lexical mastery }(\%)
\end{aligned}
$$

Based on the calculation of the percentage of krama lexical mastery with the formulation in table 1, a qualification will be applied based on the mastery level. The list of mastery level qualifications can be seen in table 2 .

Table 2. Qualification of Krama Lexical Mastery

\begin{tabular}{lcc}
\hline No. & $\begin{array}{c}\boldsymbol{\Sigma} \text { Score } \\
(\%)\end{array}$ & $\begin{array}{c}\text { Qualification of Krama } \\
\text { Lexical Mastery }\end{array}$ \\
1. & $0-20$ & Very poor \\
2. & $21-40$ & Poor \\
3. & $41-60$ & Fair \\
4. & $61-80$ & Good \\
5. & $81-100$ & Very good \\
\hline
\end{tabular}

\section{FINDINGS AND DISCUSSION}

\section{Findings}

The Javanese language has two general variations in the Javanese speech of Semarang coastal community (BJPS), the variations are 
ngoko $(\mathrm{Ng})$ and krama (Kr) (Sasangka, 2004). Ngoko (Ng) is used in informal (casual) speech between the speaker and the interlocutor, reflecting the intimacy that is not distant, and expressing the closeness of the relationship between the speaker and the interlocutor. While krama (karama lugu and krama inggil) is used in formal speech. It is used to communicate with older (respectable) people or to a stranger. Non-liruleual determinants of the use of the Javanese language for Ngoko and Krama are speakers, speech partners, speech situations, speech objectives, and the things spoken (Trahutami, 2016).

There are striking differences in the use of krama lugu and krama inggil. Krama lugu $(\mathrm{Kr}$ $\mathrm{Lg}$ ) is used between speakers and interlocutors who have a parallel/ symmetrical position (both in age and social status), but the relationship between the two is not close. Whereas krama inggil ( $\mathrm{Kr} \mathrm{Ing}$ ) is used by a speaker to speak to the interlocutor who has a higher position (not parallel/ asymmetrical), so that the speaker must respect him (Poedjosoedarmo, 1979). If the social norm is violated by the speaker, then the speech is considered impolite and not following the prescriptive normative rules of the standard Javanese language. Based on the phenomena of the language, the researcher will prove some of the language deviations that occur in the coastal areas of Semarang City through a test of basic lexical mastery. Afterward, an analysis is conducted on the selection and placement of the lexicon in the daily speech sentences.

\section{Mastery of the Krama Lexicon of Semarang Coastal Community}

The testing of krama lexical mastery to Javanese speakers in the coastal area of Semarang shows a score of $38.1 \%$ in mastery level. The score shows that the krama lexical mastery of Javanese speakers in the coastal area of Semarang is in a "poor" qualification. Details of the number of krama lexicon obtained at each research point in the coastal area in Semarang can be seen in table 3 .

Based on the recap of the calculation results in table 3, it is known that the lexical mastery of Semarang coastal speaker only reaches $38.1 \%$ of the total krama lexicon tested. The level of krama lugu lexical mastery is higher than the level of krama inggil lexical mastery.
This is also proofed by the assumption of the Javanese coastal speaker obtained from the observation and interviews that the speakers rarely use krama in everyday speech. Therefore, the coastal Javanese speakers forget that they have mastered the krama lexicon once. As a result, the use of the krama lexicon in speech utterances is limited.

Table 3. Krama Lexical Mastery of Semarang Coastal Community

\begin{tabular}{|c|c|c|c|c|c|c|}
\hline \multirow{2}{*}{ No. } & \multirow{2}{*}{$\begin{array}{c}\text { Re- } \\
\text { search } \\
\text { Point }\end{array}$} & \multicolumn{2}{|c|}{$\begin{array}{c}\text { Master } \\
\text { per speech } \\
\text { levels }\end{array}$} & \multirow{2}{*}{$\begin{array}{l}\text { The total } \\
\text { of mas- } \\
\text { tery in } \\
\text { each re- } \\
\text { search } \\
\text { point }\end{array}$} & \multirow{2}{*}{$\begin{array}{c}\text { Percent- } \\
\text { age of } \\
\text { mastery } \\
\text { per re- } \\
\text { search } \\
\text { point } \\
(\%)\end{array}$} & \multirow{2}{*}{$\begin{array}{c}\begin{array}{c}\text { Per- } \\
\text { centage } \\
\text { of mas- }\end{array} \\
\text { tery in } \\
\text { Sema- } \\
\text { rang } \\
(\%) \\
\end{array}$} \\
\hline & & $\begin{array}{l}\text { Kr } \\
\mathbf{L g}\end{array}$ & $\begin{array}{l}\mathbf{K r} \\
\text { Ing }\end{array}$ & & & \\
\hline 1. & $\begin{array}{l}\text { North } \\
\text { Sema- } \\
\text { rang } \\
\text { District } \\
\end{array}$ & 81 & 61 & 150 & 37,5 & \multirow{5}{*}{38,1} \\
\hline 2. & $\begin{array}{l}\text { West } \\
\text { Sema- } \\
\text { rang } \\
\text { District } \\
\end{array}$ & 84 & 63 & 147 & 36,75 & \\
\hline 3. & $\begin{array}{l}\text { Central } \\
\text { Sema- } \\
\text { rang } \\
\text { District }\end{array}$ & 87 & 73 & 160 & 40 & \\
\hline 4. & $\begin{array}{l}\text { Genuk } \\
\text { District }\end{array}$ & 77 & 68 & 145 & 36,25 & \\
\hline 5. & $\begin{array}{l}\text { Temba- } \\
\text { lang } \\
\text { District }\end{array}$ & 83 & 77 & 160 & 40 & \\
\hline
\end{tabular}

The lack of mastery of krama lexicon in Javanese speakers in the Semarang coastal areas results in deviations in the selection and placement of the lexicon in the utterances. The deviations occurred because the lower variant of the lexicon krama mastered, the lower the formation of sentences which accordance with prescriptive rules of standard Javanese language; the lack of krama lexical mastery also results in the absence of the right lexical selection to be used in speech utterances. Based on these assumptions, it can be concluded that the lower the level of krama lexical mastery, the higher the degree of deviation.

\section{Forms of Deviations in the Use of Javanese Krama in the Coastal Area of Semarang City}

Based on the testing results of krama lexical mastery and language skills of the Javanese speakers that have been analyzed, various forms of deviation related to the application of Javanese speech politeness and prescriptive rules of standard Javanese language are found. The forms of deviation are explained in the following discussion. 


\section{Overlapping of Speech Levels Usage}

The overlapping use of the Javanese polite speech levels is characterized by: the use of the krama lugu lexicon in krama inggil and vice versa, the use of the krama inggil lexicon for young children or interlocutors whose position (both age and social status) is lower than the speaker, and the use of the ngoko lexicon in krama. The phenomenon in the speech of Semarang coastal community can be seen in the following discussion.

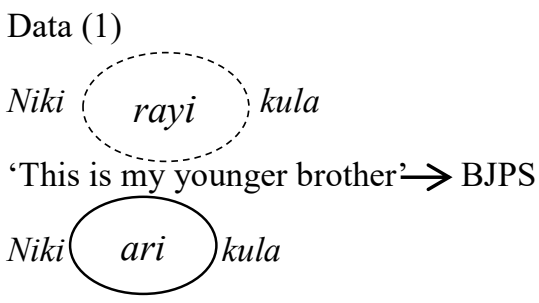

'This is my younger brother' $\rightarrow$ BJS

Rayi 'younger brother' lexicon in Standard Javanese Language (BJS) is considered to be in krama inggil ( $\mathrm{Kr}$ Ing) level and is intended for interlocutors who have a position (both age and social status) higher or not asymmetric with the speaker. In BJPS, rayi 'younger brother' lexicon is not only used in krama inggil ( $\mathrm{Kr}$ Ing), but also it is used in krama lugu $(\mathrm{Kr} \mathrm{Lg})$.

Kr Lg lexicon: ari 'younger brother' in BJS was not found in the krama speech of the BJPS. This phenomenon is influenced by the low mastery and acquisition of the krama lexicon variant, the inheritance error factor, and the lack of understanding of BJPS speakers on the use of Javanese speech levels. These factors also triggered the selection and placement of the krama lexicon in BJPS utterances not following the prescriptive rules of BJS.

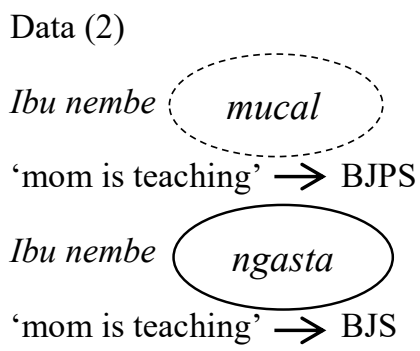

The Kr Lg: mucal 'teaching' in BJS has experienced an expansion in the speech of BJPS. It is also included in $\mathrm{Kr}$ Ing speech level in BJPS. The $\mathrm{Kr} \mathrm{Lg}$ speech level is intended for inter- locutors whose position (age and social status) is parallel or symmetrical with the speaker but the relationship between the two is not close, while the $\mathrm{Kr}$ Ing speech level is intended for interlocutors who have a position (both age and social status) that is not parallel (asymmetrical) or higher than a speaker so the speaker must respect the interlocutor by using $\mathrm{Kr}$ Ing.

$\mathrm{Kr}$ Ing lexicon: ngasta 'teaching' in BJS experiences a shift in meaning in BJPS. The shift in meaning is that the ngasta 'teaching' lexicon in BJS means 'brings' and 'work' in BJPS. The factors that influence the incorrect placement and selection of krama lexicon in BJPS utterances are low mastery and acquisition of krama lexicon variant. The low mastery of krama lexicon is the main cause of BJPS speakers could not choose the right lexicon to use in speech so that the use of the Javanese speech levels is not following BJS.

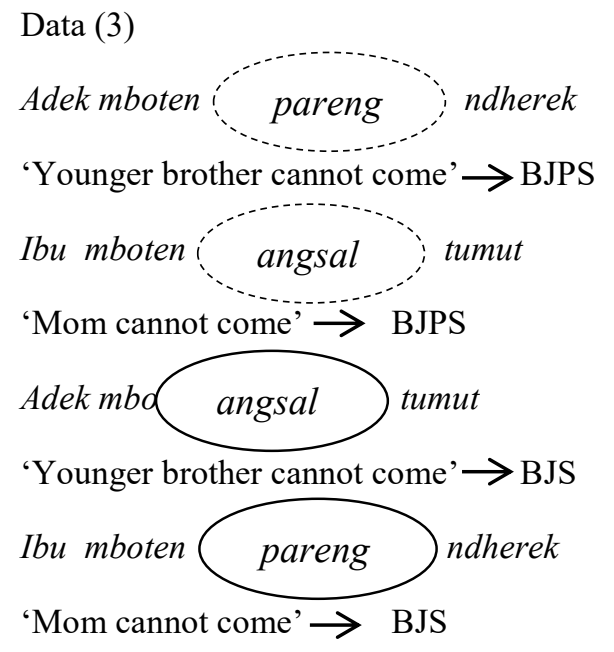

$\mathrm{Kr}$ Lg lexicon: angsal 'can' in BJS is for the interlocutor whose position (age or social status) is equal (symmetrical) but the relationship is not close with the speaker. The pareng 'can' lexicon in BJS occupies $\mathrm{Kr}$ Ing speech level and is intended for interlocutors who have a position (both age and social status) higher than the speaker. However, the standard rules are not applied in BJPS utterances. The angsal 'can' lexicon occupies the $\mathrm{Kr}$ Ing speech level and the pareng 'can' lexicon occupies the $\mathrm{Kr}$ Lg speech level in the BJPS utterance. This means that there has been a shift or misplacement of speech levels in BJPS.

Based on the results of the data validity, the deviation above is caused by the assumption of BJPS speakers that the pareng 'can' lexicon is for children, so it is not polite if the lexicon is used 
for interlocutors whose position (age or social status) is higher (asymmetric) than the speaker. This phenomenon is influenced by the mastery and acquisition of low krama lexicon variant, lack of public knowledge and understanding of the use of speech levels that should be following BJS. The existence of errors in the inheritance of language is very influential in language deviations that grow and develop in BJPS speech.

Meanwhile, the ndherek 'come' lexicon in the BJS is $\mathrm{Kr}$ Ing speech level and is only intended for interlocutors who have a higher position (age or social status) or asymmetrical with the speaker. Whereas the tumut 'come' lexicon in BJS occupies the $\mathrm{Kr} \mathrm{Lg}$ speech level and is only intended for interlocutors whose position is parallel (symmetrical) with the speaker. The ndherek and tumut 'come' lexicon experience expansion in the BJPS utterances, both lexical can occupy the $\mathrm{Kr}$ Ing and $\mathrm{Kr}$ Lg speech levels.

Some coastal communities in Semarang use the ndherek 'come' lexicon for young children with the aim of teaching and familiarizing polite Javanese language, so the children could use it when they speak to older people. This goal is very good because it can foster a sense of pride in using Krama Javanese language to children, but there is a mistake in the selection and placement of the krama lexicon. The mistake is that the selection and placement of the ndherek 'come' lexicon at $\mathrm{Kr} \mathrm{Lg}$ speech level as in Data (3) Adek mboten pareng ndherek 'younger brother cannot come'. The correct utterance that is following prescriptive rules of standard Javanese language is: Adek mboten angsal tumut 'younger brother cannot come'.

Data (4)

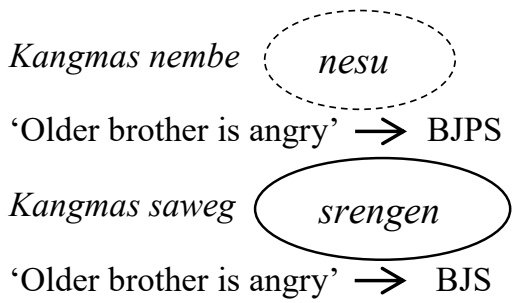

The lexicon nesu 'angry' in BJS belongs to the $\mathrm{Ng}$ speech level group and is used for familiar interlocutors, not a stranger to the speaker, and do not have to be respected by the speaker. The 'angry' lexicon is experiencing an expansion in BJPS speech. The expansion is that in addition to being classified in $\mathrm{Ng}$ speech level, the lexicon nesu 'angry' is also classified in the $\mathrm{Kr} \mathrm{Lg}$ speech level in BJPS utterances. The Kr Lg speech level is intended for interlocutors who have a parallel (symmetrical) position (both in age or social status) with the speaker but are not familiar/ stranger. Whereas the Kr Lg: srengen 'angry' lexicon in the BJS is not found in the BJPS utterance, or it can be said that the lexicon is not productive (unproductive).

Based on the validity of the data by triangulation of data sources, it can be concluded that the phenomenon that has been explained is motivated by the low mastery and acquisition of krama lexicon variant, deviations in the inheritance of languages, and the lack of understanding of BJPS speakers on the use of Javanese speech level. These factors cause deviations in the form of irregularities in the selection and placement of the krama lexicon in sentences where it is not following the prescriptive rules of Javanese standard language BJS). The lack of understanding of BJPS speakers on Javanese grammar has also led to errors in the application of polite utterances, where they still appear and even evolve in BJPS daily life.

\section{Self-Kramanisasi}

Self-kramanisasi is characterized by the use of the krama inggil lexicon for oneself, so that speakers of other languages (outside Semarang Coastal Community) address BJPS speakers as seneng mbasake awake dhewe "people who glorify themselves by using lexical that are supposed to be used to address people in higher (age or social status) position'. The form of self-kramanisasi in BJPS can be seen in the following data.

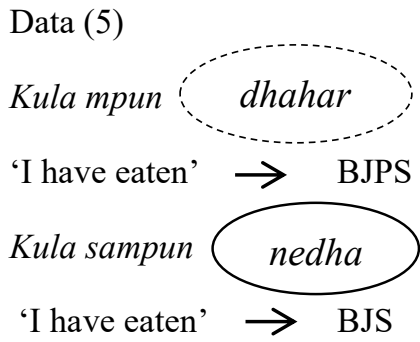

The dhahar 'eaten' lexicon in BJS belongs to the $\mathrm{Kr}$ Ing speech level group, and is intended for interlocutors whose position (age or social status) is higher or is not asymmetrical with the speaker. The dhahar 'eating' lexicon in the BJPS has expanded, the lexicon occupies the speech 
level of $\mathrm{Kr}$ Ing and $\mathrm{Kr} \mathrm{Lg}$. In addition to addressing interlocutors who have a higher position, the lexicon is also intended for interlocutors whose position is equal (symmetrical) and is also used for oneself. The use of the Kr Ing lexicon for the speaker itself is what is known as the habit of the people of Semarang who are happy to praise themselves. Whereas in the Javanese language, there is a rule that a speaker must follow namely being humble the interlocutor who must be respected.

Meanwhile, the Kr Lg: nedha 'eat' lexicon in BJS is hardly found in the krama speech of the BJPS or it can be said that the lexicon is not productive. The application deviation and inaccurate selection and placement of the lexicon in BJPS speech is due to the lack of mastery and acquisition of krama lexicon variant, errors in the inheritance of language, as well as the lack of understanding of BJPS speakers in Javanese language rules.

Another factor that caused the deviations still exist and evolve among the coastal community of Semarang City is: BJPS speakers believe that the deviation is correct of and they decided to continue to use them in everyday speech. As a result, it causes these deviations to become a collective mistake made by almost every BJPS speaker.

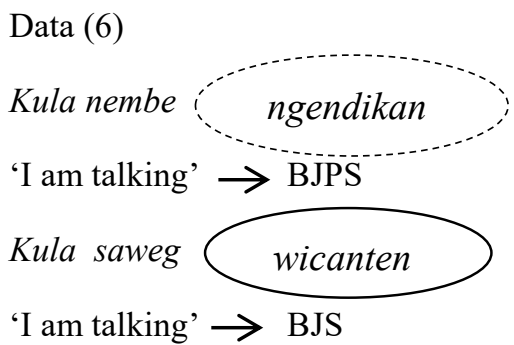

The lexicon ngendikan 'talking' is considered to be Kr Ing level in BJS and is only intended for interlocutors who have a position (both age and social status) that is not parallel (asymmetrical) or higher and must be respected by the speaker. The ngendikan 'talking' lexicon experience an expansion in BJPS utterances, the expansion of which is that the lexicon occupies the speech levels of $\mathrm{Kr}$ Ing and $\mathrm{Kr} \mathrm{Lg}$. Whereas the $\mathrm{Kr}$ Lg: wicanten 'talking' lexicon was not found in the BJPS utterance. BJPS speakers do not recognize the wicanten 'talking' lexicon as a krama lexicon variant. Based on the triangulation of data sources, it is concluded that ignorance is caused by low mastery and acquisition of krama lexical variant. This is also caused by the lack of understanding of the BJPS community on the use of speech levels which should be following standard Javanese language grammar, so that the selection and placement of the lexicon in the speech sentence is not following the prescriptive rules.

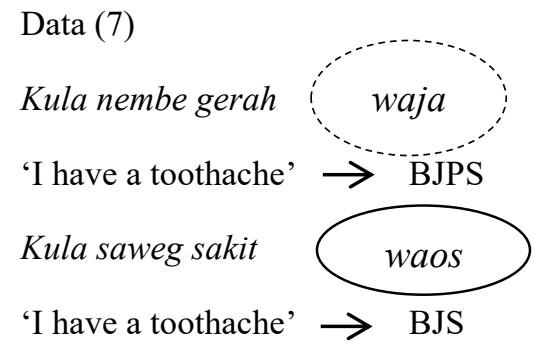

The waja 'teeth' lexicon in BJS belongs to the $\mathrm{Kr}$ Ing speech level group, the lexicon is only for interlocutors who have a higher position (age or social status) or are not asymmetrical with the speaker. The waja 'teeth' lexicon in the BJPS has expanded, in addition to the $\mathrm{Kr}$ Ing speech level, the lexicon is also used in the $\mathrm{Kr} \mathrm{Lg}$ speech level group. The $\mathrm{Kr} \mathrm{Lg}$ speech level is intended for interlocutors who have a position (age and social status) parallel (symmetrical) with the speaker but are not familiar.

The coastal community of Semarang only master the lexicon of waja 'teeth in krama. BJPS speakers do not know other krama lexicon variant, so BJPS speakers only use the lexicon they master. Meanwhile, waos 'teeth' lexicon in $\mathrm{Kr}$ Lg level based on BJS was not found in the BJPS utterance. The deviation in the selection and placement of the krama lexicon in the speech makes speakers of other languages (besides BJPS) assume that Semarang coastal community love to praise themselves. The language phenomenon also applies to the $\mathrm{Kr}$ Ing lexicon: gerah 'sick' which was used to describe themselves.

Based on observations and interviews with several respondents, the main trigger for this phenomenon is the low mastery and acquisition of the krama lexicon variant that is influenced by the language inheritance errors of the speaker's fami$\mathrm{ly} /$ area of the speaker's residence. In addition, the cause of the low mastery of the krama lexicon variant is the lack of education of Javanese language grammar, so that the BJPS community are not able to choose and place the krama lexicon in their speech (Wibawa, 2015). 
Data (8)

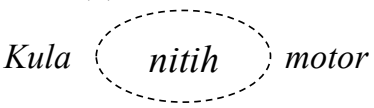

'I am riding a motorcycle' $\rightarrow$ BJPS

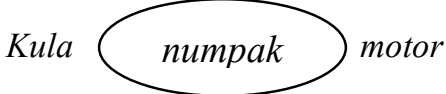

'I am riding a motorcycle' $\rightarrow$ BJS

The nitih 'riding' lexicon in the BJS belongs to the $\mathrm{Kr}$ Ing group of speech level, but in BJPS, the lexicon has expanded to another level. In BJPS, the lexicon is also considered to be in $\mathrm{Kr}$ $\mathrm{Lg}$ speech level group. The $\mathrm{Kr} \mathrm{Lg}$ lexicon: numpak 'riding' in BJS is considered to be $\mathrm{Ng}$ lexicon in BJPS, while the $\mathrm{Ng}$ lexicon for riding in BJS is nunggang. People in coastal areas of Semarang rarely use the nunggang 'riding' lexi-con in their ngoko speech because BJPS speakers assume that the nunggang 'riding' lexicon is impolite if intended for humans.

The use of nitih 'riding' lexicon for the speaker himself in BJPS speech is called a phenomenon of kramanisasi by BJS speakers, it is also considered that BJPS speakers have praise themselves by using the lexicon. Based on the validity of the data by triangulation of data sources, it is concluded that some of these phenomena are influenced by the low mastery and acquisition of krama lexicon variant. The inheritance error of the language of the family and the environment where the speaker lives also result in a misunderstanding of BJPS speakers' understanding of the use of Javanese speech levels. These factors have an impact on the selection and placement of the krama lexicon in BJPS utterances which are not following the prescriptive rules of standard Javanese language (BJS).

Data (9)

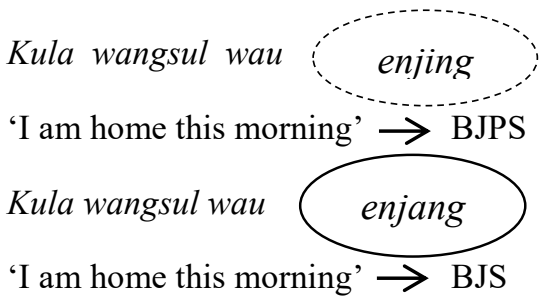

The Kr Ing lexicon: enjing 'morning' in BJS is only intended for interlocutors who have a higher position than the speaker, but in Data 9, the lexicon is also used in different speech levels by BJPS. The lexicon is also used in $\mathrm{Kr} \mathrm{Lg}$ speech level, which means the lexicon enjing 'morning' is used when a speaker speaking to an interlocutor who has the same or different age or social status.

Kr Lg's lexicon: enjang 'morning' in BJS is less productive in BJPS speech. Although some BJPS speakers know that there is a variant of enjang 'morning' lexicon, the BJPS speakers tend to use the enjing 'morning' lexicon 'in their utterances. In fact, there is an assumption among BJPS speakers that enjing and enjang 'morning' are at the same speech level. Both lexicons are both krama lexicons and their selection in speech is arbitrary without considering the level of $\mathrm{Kr} \mathrm{Lg}$ or Kr Ing speech.

From the conclusions obtained through triangulation of data sources, the phenomenon in Data (9) is influenced by the belief of the speaker that the lexicon used by the BJPS speaker in the speech is correct and does not need to be questioned. The mistake was made continuously because of the pure agreement between BJPS speakers. Therefore, this error is a collective error that is considered as truth. In addition, the low understanding of BJPS speakers on the use of the speech levels is also the main trigger for the selection and placement of the krama lexicon in the speech sentence not following the prescriptive rules of the standard Javanese language (BJS).

\section{Indonesian Language Interference on Java- nese Language}

Interference between Javanese language and Indonesian language is marked by the use of the Indonesian language lexicon as an effort to refine speech because speakers do not master the krama lexicon variant. The phenomenon of language interference in BJPS speakers can be seen in Data (10) and Data (11) below.

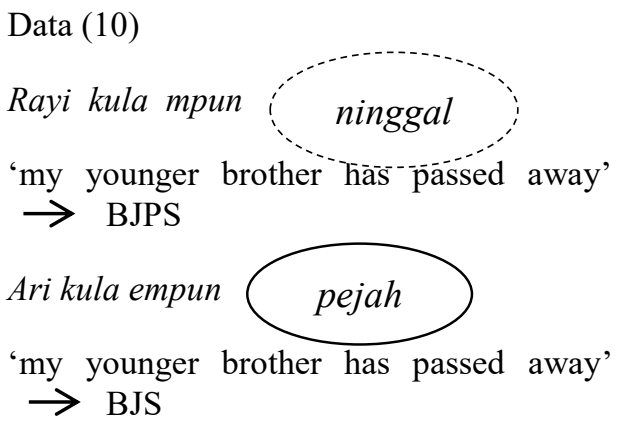


The pejah 'dead/passed away' lexicon in the BJS belongs to the group of $\mathrm{Kr} \mathrm{Lg}$ speech level. The pejah 'dead/passed away' lexicon experiences a shift and is not productive in BJPS speech. In BJPS, the lexicon ninggal 'dead/ passed away' is used as if it is in $\mathrm{Kr} \mathrm{Lg}$. The lexicon ninggal is adopted from Indonesian language. The ninggal 'dead/ passed away' lexicon is considered a delicate lexicon in BJPS and is used to refine the 'dead/passed away' lexicon when it is intended for humans. The mati lexicon 'dead' is considered rude by BJPS speakers if it is addressed for humans.

Based on the conclusions from various data sources, it can be concluded that the linguistic phenomenon found in the use of the 'dead/ passed away' lexicon in the BJPS utterance is influenced by the low mastery and acquisition of the krama lexicon variant. Therefore, the ability of BJPS speakers to choose the 'dead/passed away' lexicon variant is very limited. The lack of understanding of BJPS speakers on the correct use of Javanese speech levels triggers the inaccurate selection and placement of the krama lexicon in speech sentences. It causes the delicate speech sentences do not comply with the rules (prescriptive rules) in Standard Javanese language (BJS).

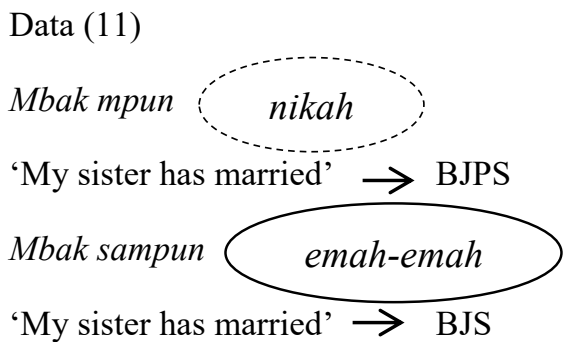

The emah-emah 'married' in BJS belongs to the $\mathrm{Kr} \mathrm{Lg}$ speech level group, while the 'married' lexicon belongs to $\mathrm{Kr}$ Ing speech level group. The emah-emah and 'married' lexicon are unproductive in BJPS speech. BJPS speakers tend to use the nikah 'married' lexicon, which is adopted from Indonesian language. The nikah 'married' lexicon is considered to be a delicate lexicon to replace the $\mathrm{Ng}$ lexicon: kawin 'married' in BJS. The nikah 'married' lexicon is considered to be normal and proper by BJPS so they use it in daily speech. Although this is considered to be an error by BJS speakers, this error has become a collective mistake that is almost always made by every Javanese speaker in the Semarang coastal area (BJPS).
The conclusions obtained from the triangulation of data sources on the linguistic phenomenon in Data (11) are influenced by the low mastery of the 'married' krama lexicon variant so that there are no other lexical selection that are following the prescriptive rules of the standard Javanese language when BJPS speakers want to use it in a speech sentences.

\section{Discussion}

\section{The Selection and Placement of the Krama Lexicon in the Polite Javanese Speech of Sema- rang Coastal Community}

BJPS has its characteristics compared to other Javanese languages. The characteristics are in the form of krama inggil lexicon use in the speech. The way BJPS speakers respect their interlocutors is also not the same as standard Javanese speakers (hereafter: BJS). BJS speakers only use the krama inggil lexicon for interlocutors whose age and social status are higher, and are respected. While the language phenomena found in the city of Semarang, BJPS speakers sometimes use the krama inggil lexicon not only for interlocutors whose position (age or social status) is higher than the speaker but also for themselves even though it is intended to respect the interlocutor.

Based on the results of language mastery tests that have been analyzed, it is found that there are various forms of deviations related to the use of Javanese grammar and prescriptive rules of standard Javanese language. As for the forms of deviations are: (1) overlapping use of Javanese speech levels marked by: the use of the krama lugu lexicon in krama inggil level or vice versa, the use of krama inggil lexicon to address young children, and the use of ngoko lexicon in krama; (2) self-kramanisasi which is marked by the use of the krama inggil lexicon for oneself; (3) Javanese language interference by Indonesian language, marked by the use of the Indonesian language lexicon as an effort to refine the utterance; (4) the formation of deviations in the language of Semarang coastal community, where they believ-ed that the deviations are something normal and it becomes a collective mistake; and (5) the use of Javanese language in BJPS utterances is not following the prescriptive rules of the SoloYogyakarta standard Javanese language, charac- 
terized by the freedom of speakers to place the lexicon at the speech levels.

The factors causing deviations in the Javanese language of Semarang coastal community are: (1) the lower the lexical mastery level of a Javanese speaker, the lower the ability to produce speech sentences which following the prescriptive normative rules of the standard Javanese language; (2) the low acquisition of the krama lexicon in BJPS speakers and the limited selection of the lexicon in speech; (3) deviations are carried out continuously, from generation to generation, so that these deviations increasingly grow and evolve in the next generation; (4) the inheritance error factor of language originating from the family and community where BJPS speakers live; and (5) lack of understanding of the use of speech levels that following standard Javanese language grammar.

The results of this research complement the results of previous research related to the inaccuracy in the use of the Krama Javanese language according to standard rules, or in this research called the standard Javanese language oriented on the Solo-Yogya Javanese language. The results of previous research have not specifically mentioned the deviations as well as the factors that cause it related to the use of standard Javanese language in coastal areas.

\section{CONCLUSION}

The mastery of the Krama Javanese lexicon in the coastal community of Semarang is in a

\section{REFERENCES}

Azizah, S. N. (2008). Pemilihan Bahasa di Ranah Rumah Tangga (Studi Kasus Desa Pakulaut Kec. Margasari dan Desa Slawi Kulon Kec. Slawi Kabupaten Tegal). Skripsi. Semarang: Fakultas Ilmu Budaya Universitas Diponegoro.

Bachri, B. S. (2010). Meyakinkan Validitas Data Melalui Triangulasi pada Penelitian Kualitatif. Teknologi Pendidikan, 10: 46-62.

Handono, S. (2004). Tinggal 26,16\% Warga Semarang yang Masih Setia Menggunakan Bahasa Jawa. In Seranta Bahasa \& Sastra 2004 (pp. 1-29). Pusat Bahasa.

Laksono, K. (2006). Pengembangan Bahasa dan Sastra Jawa dalam Perspektif Kebhinekatunggalikaan. "poor" qualification. This qualification is indicated by the percentage of mastery which only reached $38,1 \%$ from the 100 (one hundred) basic lexicons tested. In brief, the lexical mastery in BJPS speakers is caused by some factors, namely: the limited acquisition of krama lexicon variant in the family or community where the speaker lives, the collective mistakes used continuously by the speakers, the speakers rarely use krama in everyday speech, and lack of understanding of standard Javanese language rules.

The selection of krama lexicon in BJPS speakers is very low because the lexical mastery level was only $38,1 \%$. The lack of mastery of the krama lexicon causes the selection and placement of the lexicon in speech utterances to be very limited. It is also the main cause of the low acquisition of the krama lexicon variant in Semarang coastal community. As a result, the speech sentences used by BJPS speakers in daily interactions are not following the standard Javanese language rules.

This research on the use of Javanese language in the coastal area of Semarang City is not perfect, because it only examines the level of mastery of the krama lexicon as well as the selection and placement in daily speech sentences. The research does not cover the prescriptive rules of standard Javanese language as a whole, so it is necessary to conduct further research related to the complete application of standard Javanese language in coastal community, including phonology, morphology, and syntax aspects.

Kongres Bahasa Jawa IV: Komisi Kearifan Lokal, 85-97.

Poedjosoedarmo, S. (1979). Tingkat Tutur Bahasa Jawa. Pusat Pembinaan dan Pengembangan $\mathrm{Ba}-$ hasa.

Pujiastuti, S., Surono, \& Mayzah, S. (2009). Keengganan Bertutur Jawa Akibat Rendahnya Penguasaan Leksikon Dasar Bahasa Jawa. In Laporan Penelitian Hibah Bersaing Dikti Jakarta. Fakultas Ilmu Budaya Universitas Diponegoro. http://eprints.undip.ac.id/1036/

Purwoko, H. (2008). Jawa Ngoko: Ekspresi Komunikasi Arus Bawah. Semarang: PT INDEKS Anggota IKAPI.

Santoso, B. (2006). Bahasa dan Sastra Jawa di Tengah 
Kemajuan Teknologi. Prosiding Kongres $\mathrm{Ba}$ hasa Jawa IV, 171-175.

Sasangka, S. S. T. W. (2004). Unggah Ungguh Bahasa Jawa. Jakarta: Yayasan Paramalingua.

Sudaryanto. (1991). Tata Bahasa Baku Bahasa-Jawa. Yogyakarta: Duta Wacana University Press.

Sudaryanto. (2015). Metode dan Aneka Teknik Analisis Bahasa: Pengantar Penelitian Wahana Kebudayaan secara Linguistis. Yogyakarta: Sanata Dharma University Press.

Sundoro, B. T., Suwandi, S., \& Setiawan, B. (2018). Campur Kode Bahasa Jawa Banyumasan dalam Pembelajaran Bahasa Indonesia di Sekolah Menengah Kejuruan. RETORIKA: Jurnal Bahasa, Sastra, dan Pengajarannya, 11(2): 129. 139. https://doi. org/10.26858/retorika. v11i2.6367
Suryadi, M. (2014). Penggunaan Tingkat Tutur Bahasa Jawa Ngoko dan Krama pada Ranah Keluarga dan Masyarakat di Kota Semarang dan Kota Pekalongan. Disertasi. Solo: UNS.

Suryadi, M. (2015). Keunikan Tuturan Halus Basa Semarangan Sebagai Salah Satu Bentuk Kesantunan Bertutur Pada Masyarakat Jawa Pesisir. PAROLE: Journal of Linguistics and Education. https://doi.org/10.14710/parole.v5i1.9074

Trahutami, S. I. (2016). Pemilihan Tingkat Tutur Bahasa Jawa pada Masyarakat Desa Klapaduwur Blora. Culture.

Wibawa, S. (2015). Identifikasi Ketidaktepatan Penggunaan Unggah Ungguh Bahasa Jawa Mahasiswa Program Study Pendidikan Bahasa Jawa. In Litera (Vol. 4, Issue 2). https://doi.org/10. 21831/ltr.v4i2.6791 